\title{
More than just SIDS: local solutions for global problems on small islands
}

\author{
Jan Petzold \\ Alfred-Wegener-Institute for Polar and Marine Research, Germany \\ jan.petzold@awi.de \\ Beate M.W. Ratter \\ Institute of Geography, University of Hamburg, Germany \\ beate.ratter@uni-hamburg.de
}

\begin{abstract}
Small islands are often taken as poster children for climate change vulnerability, and their status as hotspots of climate change impacts has been widely acknowledged in the scientific literature. In many cases, however, individual studies as well as reviews and global assessments, generalise small islands as a whole - often with a strong focus on Small Island Developing States (SIDS) - and lack a thorough understanding of island specificity, relationality, and context dependency. Looking at small islands' issues beyond SIDS implies the recognition of topics such as asymmetrical governance structures, archipelagic centre-periphery relationships, as well as intra- and inter-island movements in various types of island territories and geographies worldwide. This special thematic section of Island Studies Journal features contributions from the Atlantic, Indian, Pacific Ocean, and Caribbean dealing with the locally specific challenges and opportunities of adaptation to environmental and climate change.
\end{abstract}

Keywords: adaptation, climate change, mitigation, small islands, sustainability, vulnerability

https://doi.org/10.24043/isj.77

(C) 2019-Institute of Island Studies, University of Prince Edward Island, Canada.

\section{Introduction}

The vulnerability of small islands to climate change is acknowledged widely in research (Nurse et al., 2014). Especially, Small Island Developing States (SIDS) are often at the centre of attention, not only in political forums and media but also in scientific publications. Kelman (2018) showed how 'islandness' is represented as an element of SIDS vulnerability in climate change narratives. A generalisation of islands under SIDS and the lack of attention to other island territories risks a faulty understanding of island-specific factors of vulnerability and potentials for adaptation. Hence, recent discussions in climate change research about small islands stress their diversity and the importance of context dependency in relation to adaptation. Such research looks "beyond the core" (Nunn et al., 2014) and at blind spots, such as peripheral dependent islands and sub-national island jurisdictions (SNIJ) (Petzold \& Magnan, 2019).

As islands represent places of condensation, where the general can be found in the specific and the specific in the general, they provide the opportunity to read and analyse different expressions of global impacts. They offer a condensate of networks that are superimposed and add to each other and connect the world to islands, which appear on maps as focal points of an infinity of lines (Bernardie-Tahir, 2011, p. 296). Island studies, with its very broad view on island geographies and environments of any type and its analysis of island relationality, archipelagic constellations, centre-periphery relationships, remoteness, and isolation, can make an important contribution towards island-specific and island-centred research on climate change vulnerability, 
impacts and adaptation (Grydehøj, 2019). The contributions of Pugh $(2013,2016)$ and Stratford et al. (2011), amongst others, reflected on archipelago constellations and an understanding of islands as part of their relations among each other. Similarly, islands and archipelagos invite studying centre-periphery relationships and inter-islands networks (Favole \& Giordana, 2018; Grydehøj \& Casagrande, 2019). A reoccurring topic in island studies is the specific status of SNIJs, e.g. concerning economic development and postcolonial politics (Baldacchino \& Milne, 2006; Karlsson, 2009; Ferdinand, 2018).

Since Island Studies Journal's founding in 2006, it has published 13 articles focused on climate change concerns, nine of which appeared in the journal's recent special thematic section on 'Small island perspectives on climate change' (Walshe \& Stancioff, 2018). That special thematic section lays the groundwork for highlighting local perspectives on climate change matters and connecting them to the island studies discourse. Featured contributions showed the importance of acknowledging diverse perceptions and experiences of climate change across various island communities and avoiding continental and global north opinions on island matters.

This follow-up special thematic section gathers further contributions that highlight the local action element for sustainable climate change adaptation and mitigation. This special thematic section includes case studies from islands in the Atlantic, Indian, and Pacific Oceans as well as the Caribbean (see Figure 1). Moreover, the five featured articles cover the different types of island territories with respect to their political and geographical representation, including: an often neglected SIDS archipelago (Cape Verde) in the Atlantic; islands that are part of a SIDS (Laamu, Maldives and Tanna, Vanuatu) in the Indian and Pacific Oceans; two SNIJs (St Barthélemy and Réunion, France) in the Caribbean and the Indian Ocean; and a dependent island of a continental state (Gran Canaria, Spain) in the Atlantic Ocean.

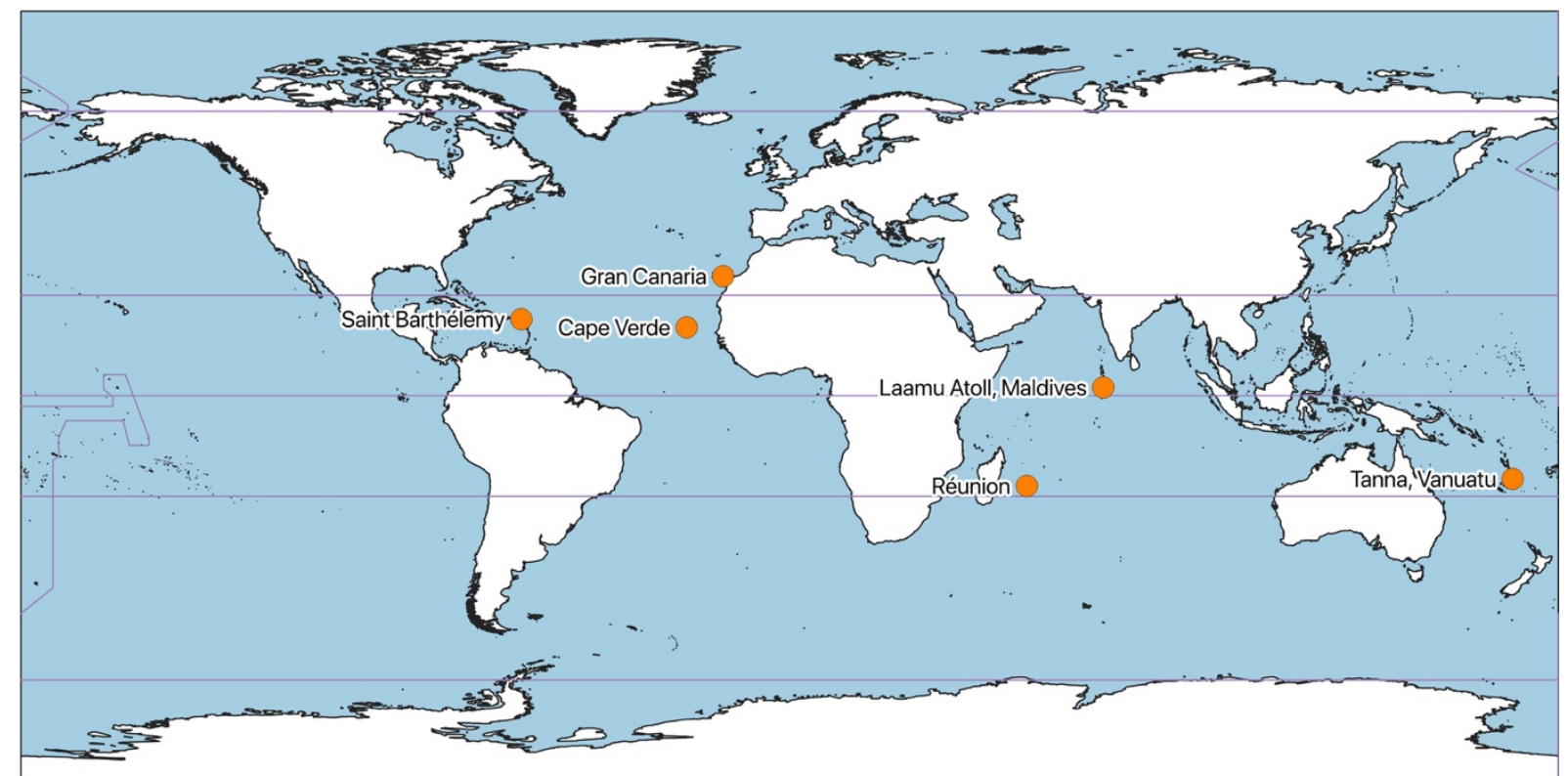

Figure 1: Map of case studies included in the special thematic section.

\section{Local island action across the globe}

The paper by Howell and Fielding (2019) on sustainable behaviour for waste and water management in St Barthélemy shows how the alleged factors of island vulnerability, such as smallness, isolation, and lack of natural resources, are countered by islanders' strong place attachment and connection to their community. These factors are even more important given the increasing global pressures the island faces, including climate change.

Ribalaygua et al. (2019) focus on spatial planning in the context of climate change by comparing two Outermost Islands of the European Union: Gran Canaria and Réunion. In both 
cases, local administrations have to consider key socio-economic issues to effectively integrate adaptation into spatial planning - in the former case study mainly regarding tourism, and in the latter regarding population growth. Both islands depend on the guidelines of the European Union's adaptation strategy as well as the regulatory frameworks and degree of support from their mother countries Spain and France.

The contribution by Nordman et al. (2019) provides an assessment of renewable energy potentials on Cape Verde, which is a SIDS composed of nine inhabited islands and often neglected in scholarship on SIDS (which focuses mainly on the Pacific, Indian Ocean, and Caribbean islands). The authors critically assess the various technological approaches and their potentials across the archipelago's individual islands as well as the implications of the ambitious goal of achieving 100 per cent renewable electricity by 2025 .

The article by Clarke et al. (2019) on community-based adaptation on Tanna, Vanuatu, contributes a case study from a peripheral island that is part of a larger archipelagic SIDS and is considered among the most vulnerable ones in the context of climate change. The authors analyse crucial elements for successful local adaptation: e.g. the involvement of local communities and their knowledge; thorough time and resource allocation for transformative change; and considerations of social justice, especially concerning gender and marginalised people.

Finally, the special thematic section includes a paper on Laamu Atoll, which is part of the Maldives. McNamara et al. (2018) analyse how peripherality is influencing vulnerability and exposure. The study shows how differences in impacts on livelihoods as well as access to resources and services between the core and peripheral islands in an archipelago matter for climate change adaptation strategies.

\section{Vulnerability and resilience as island characteristics}

The discourses surrounding climate change adaptation and sustainable development represent significant challenges to island communities in the $21^{\text {st }}$ Century. However, such perspectives are also flawed and often simplistic if not outright dangerous for island communities. Adaptation to climate change impacts is not merely a question of technological solutions but also a social challenge, as it is framed by various socio-political and economic settings, coping capacities and national-international relations. The resilience of island communities may be underestimated, but exemplary approaches present the sustainable management of future developments (Petzold \& Ratter, 2018).

The articles included in this special thematic section refer to the role of territorial status and different scales of action: independent island states with national plans for adaptation and mitigation; islands that are semi-autonomous in their planning but depend on or are influenced by continental mother states for effective implementation; and non-autonomous islands that heavily rely on their own local action. Archipelagic constellations, differences between islands of an archipelagic state, power relations, and local place attachment are further elements we can learn from. Island studies provides the important lens of context specificity for analysing these elements. Such an analysis can support adaptation by learning from the locals, acknowledging and understanding their place-specific problems, and help to avoid potentially maladaptive outcomes from one-size-fits-all solutions.

Islands are not only poster children in climate change questions but can serve as exemplifications of specific actions and illustrate the importance of space, spatial relations and dependencies, power structures and connections. Since the world of islands is composed of more than just SIDS, it is worth looking beyond and scrutinising instructive examples from which we can learn. We hope you will enjoy the special thematic section on more than just SIDS. 


\section{References}

Baldacchino, G., \& Milne, D. (2006). Exploring sub-national island jurisdictions: an editorial introduction. The Round Table, 95(386), 487-502. https://doi.org/10.1080/00358530600929735

Bernardie-Tahir, N. (2011). L'usage de l'île. Paris: Éditions Pétra.

Clarke, T., McNamara, K.E., \& Nunn, P.D. (2019). Community-based adaptation to climate change: lessons from Tanna Island, Vanuatu. Island Studies Journal, 14(1), 59-80.

Favole, A. \& Giordana, L. (2018). Islands of islands: responses to the centre-periphery fractal model in East Futuna (Wallis and Futuna) and the Belep Islands (New Caledonia). Island Studies Journal, 13(1), 209-222. https://doi.org/10.24043/isj.42

Ferdinand, M. (2018). Subnational climate justice for the French Outre-mer: postcolonial politics and geography of an epistemic shift. Island Studies Journal, 13(1), 119-134. https://doi.org/10.24043/isj.49

Grydehøj, A. (2019). Critical approaches to island geography. Area, ahead of print. https://doi.org/10.1111/area.12546

Grydehøj, A., \& Casagrande, M. (2019). Islands of connectivity: Archipelago relationality and transport infrastructure in Venice Lagoon. Area, ahead of print. https://doi.org/10.1111/area.12529

Howell, L., \& Fielding, R. (2019). Motivating sustainable behavior: waste management and freshwater production on the Caribbean island of Saint Barthélemy. Island Studies Journal, 14(1), 9-20.

Karlsson, A. (2009). Sub-national island jurisdictions as configurations of jurisdictional powers and economic capacity. Island Studies Journal, 4(2), 139-162.

Kelman, I. (2018). Islandness within climate change narratives of small island developing states (SIDS). Island Studies Journal, 13(1), 149-166. https://doi.org/10.24043/isj.52

McNamara, K.E., Clissold, R., Piggott-McKellar, A., Buggy, L., \& Azfa, A. (2019). What is shaping vulnerability to climate change? The case of Laamu Atoll, Maldives. Island Studies Journal, 14(1), 81-100.

Nordman, E., Barrenger, A., Crawford, J., McLaughlin, J., \& Wilcox, C. (2019). Options for achieving Cape Verde's 100\% renewable electricity goal: a review. Island Studies Journal, 14(1), 41-58.

Nunn, P.D., Aalbersberg, W., Lata, S. \& Gwilliam, M. (2014). Beyond the core: community governance for climate-change adaptation in peripheral parts of Pacific Island Countries. Regional Environmental Change, 14(1), 221-235. https://doi.org/10.1007/s10113-013-0486-7

Nurse, L.A., McLean, R.F., Agard, J., Briguglio, L., Duvat-Magnan, V., Pelesikoti, N., Tompkins, E.L., \& Webb, A.P. (2014). Small islands. In V.R. Barros et al. (Eds.) Climate change 2014: impacts, adaptation, and vulnerability (pp. 1613-1654). Cambridge \& New York: Cambridge University Press.

Petzold, J., \& Magnan, A.K. (2019). Climate change: thinking small islands beyond Small Island Developing States (SIDS). Climatic Change, 152(1), 145-165. https://doi.org/10.1007/s10584-018-2363-3

Petzold, J., \& Ratter, B.M.W. (2018). Island vulnerability and resilience. In B.M.W. Ratter, Geography of small islands: outposts of globalisation (pp. 173-199). Cham: Springer. https://doi.org/10.1007/978-3-319-63869-0 6

Pugh, J. (2016). The relational turn in island geographies: bringing together island, sea and ship relations and the case of the Landship. Social \& Cultural Geography, 17(8), 1040-1059. https://doi.org/10.1080/14649365.2016.1147064

Pugh, J. (2013). Island movements: thinking with the archipelago. Island Studies Journal, 8(1), 9-24.

Ribalaygua, C., García, F., \& García Sánchez, H.J. (2019). Outermost European islands and climate change adaptation: a new role for regional planning. Island Studies Journal, 14(1). 
Stratford, E., Baldacchino, G., McMahon, E., Farbotko, C., \& Harwood, A. (2011). Envisioning the archipelago. Island Studies Journal, 6(2), 113-130.

Walshe, R.A., \& Stancioff, C.E. (2018). Small island perspectives on climate change. Island Studies Journal, 13(1), 13-24. https://doi.org/10.24043/isj.56 
Jan Petzold \& Beate Ratter 